\title{
Use of Physical and Biological Process Models to Understand the Performance of Tubular Anaerobic Digesters
}

1. Maureen N Kinyua

Affiliation address: Department of Civil and Environmental Engineering, University of South Florida, 4202 E Fowler Ave ENB 118 Tampa, FL 33620

Current address: Department of Earth and Environmental Engineering, Columbia

University, 500 W. $120^{\text {th }}$ St. 918 S. W. Mudd Hall, 500, Manhattan, NY 10027

mk3855@columbia.edu

2. Jie Zhang

Department of Civil and Environmental Engineering, University of South Florida, 4202 E

Fowler Ave ENB 118 Tampa, FL 33620

jiez@mail.usf.edu

3. Fabricio Camacho-Céspedes

University of Georgia, Costa Rica, Apartado 108-5655 Santa Elena de Monteverde

Puntarenas, Costa Rica

fabricio@uga.edu

4. Andres Tejada-Martinez

Department of Civil and Environmental Engineering, University of South Florida, 4202 E

Fowler Ave ENB 118 Tampa, FL 33620

aetejada@usf.edu

5. Sarina J. Ergas*

Department of Civil and Environmental Engineering, University of South Florida, 4202 E

Fowler Ave ENB 118 Tampa, FL 33620

sergas@usf.edu

813-974-1119

*corresponding author 


\begin{abstract}
Tubular anaerobic digesters are used in developing countries to produce biogas from livestock waste. In this research, field measurements and physical and biological process modeling studies were used to investigate transport and transformation mechanisms for particulate and soluble organic matter in household-scale tubular digesters in the Monteverde region of Costa Rica. Greater than $75 \%$ removal of volatile solids and biochemical oxygen demand $\left(\mathrm{BOD}_{5}\right)$ were observed. The high effluent quality was attributed to the formation of a biologically active floccular sludge layer, which allowed for separation of hydraulic and mean cell residence times (HRT and MCRT). A reduced order transport model was developed and validated using field tracer study data. Key assumptions of the reduced order model were verified via computational fluid dynamics (CFD) analysis. The mean HRT predicted by the reduced order model was 23 days and was in good agreement with the tracer experiment. A simplified floccular sludge biological process model was developed and used to estimate an average MCRT of 115 days. The results showed that household-scale tubular anaerobic digesters can provide enough biogas to meet households' cooking energy needs, which was consistent with field results. This is the first study to combine mathematical modeling with field studies of tubular anaerobic digester performance.
\end{abstract}

\title{
Keywords:
}

Anaerobic processes; Bioreactors; Computational fluid dynamics; Modeling; Tubular anaerobic digester; Waste treatment 


\section{List of Equation Nomenclature}

$\begin{array}{lll}\mu_{t} & \text { Eddy viscosity } & \mathrm{N} \cdot \mathrm{s} / \mathrm{m}^{2} \\ C & \text { Ensemble-averaged tracer concentration } & \mathrm{g} \mathrm{KCl} / \mathrm{L} \\ C^{\prime} & \text { Tracer fluctuation and flux } & \mathrm{g} \mathrm{KCl} / \mathrm{L} \\ C_{d} & \text { Tracer concentration in the digester } & \mathrm{g} \mathrm{KCl} / \mathrm{L} \\ C_{i n} & \text { Influent tracer concentration } & \mathrm{g} \mathrm{KCl} / \mathrm{L} \\ C_{o} & \text { Initial tracer concentration in the digester } & \mathrm{g} \mathrm{KCl} / \mathrm{L} \\ C_{\text {out }} & \text { Effluent tracer concentration } & \mathrm{g} \mathrm{KCl} / \mathrm{L} \\ D_{t} & \text { Eddy (turbulent) diffusivity } & \mathrm{m}^{2} / \mathrm{s} \\ k & \text { Turbulent kinetic energy } & \mathrm{J} / \mathrm{kg}^{-2} \mathrm{~m}^{2} / \mathrm{s}^{2} \\ K_{d} & \text { Biomass cell decay coefficient } & \mathrm{day} \\ K_{m} & \text { Maximum specific substrate utilization rate } & \mathrm{g} \mathrm{COD} \mathrm{utilized} / \mathrm{g} \text { biomass COD-day } \\ K_{S} & \text { Biomass half saturation constant } & \mathrm{g} \mathrm{COD} / \mathrm{L} \\ \dot{\mathrm{m}} & \text { Daily methane production rate } & \mathrm{g} \mathrm{COD} / \mathrm{day} \\ n & \text { Current day } & \mathrm{Day} \\ p & \text { Reynolds-averaged pressure } & \mathrm{Pa} \\ Q & \text { Flow } & \mathrm{L} / \mathrm{day} \\ S_{b} & \text { Soluble substrate concentration } & \mathrm{g} \mathrm{COD} / \mathrm{L} \\ S_{C H 4} & \text { Methane content } & \% \\ S c_{t}, & \text { Schmidt number } & \mathrm{dimensionless} \\ t & \text { Time } & \mathrm{day} \mathrm{or} \mathrm{hour} \\ T & \text { Flow-through period } & \mathrm{Minute} \\ u_{i} & \text { Reynolds-averaged velocity } & \mathrm{m} / \mathrm{s} \\ v & \text { Kinematic viscosity } & \mathrm{m}^{2} / \mathrm{s} \\ V & \text { Volume } & \mathrm{L} \\ x_{i} & \text { Position } & \mathrm{M} \\ X_{m} & \text { Active digester biomass concentration } & \mathrm{g} \mathrm{COD} / \mathrm{L} \\ X_{m e} & \text { Active biomass in effluent concentration } & \mathrm{g} \mathrm{COD} / \mathrm{L} \\ X_{m i} & \text { Active biomass in influent concentration } & \mathrm{g} \mathrm{COD} / \mathrm{L} \\ Y_{m} & \text { Biomass yield coefficient } & \mathrm{g} \mathrm{biomass} \mathrm{COD} / \mathrm{g} \mathrm{COD} \mathrm{utilized} \\ \varepsilon & \text { Turbulent kinetic energy dissipation rate } & \mathrm{m}{ }^{2} / \mathrm{s}^{3} \\ \rho & \text { Density } & \mathrm{kg} / \mathrm{m}^{3} \\ & & \end{array}$




\section{List of Acronyms}

$\begin{array}{ll}\text { ADM1 } & \text { Anaerobic Digestion Model 1 } \\ \text { BOD }_{5} & \text { Five day Biochemical Oxygen Demand } \\ \text { CFD } & \text { Computational Fluid Dynamics } \\ \text { CSTR } & \text { Completely Stirred Tank Reactor } \\ \text { HRT } & \text { Hydraulic Retention Time } \\ \text { FOG } & \text { Fats Oils Grease } \\ \text { LCFA } & \text { Long Chain Fatty Acids } \\ \text { MCRT } & \text { Mean Cell Retention Time } \\ \text { OLR } & \text { Organic Loading Rate } \\ \text { RANS } & \text { Reynolds-Averaged Navier-Stokes } \\ \text { STP } & \text { Standard Temperature Pressure } \\ \text { SVI } & \text { Sludge Volume Index } \\ \text { TAN } & \text { Total Ammonia Nitrogen } \\ \text { TN } & \text { Total Nitrogen } \\ \text { TP } & \text { Total Phosphorus } \\ \text { TS } & \text { Total Solids } \\ \text { UASB } & \text { Upflow Anaerobic Sludge Blanket } \\ \text { VFA } & \text { Volatile Fatty Acids } \\ \text { VS } & \text { Volatile Solids }\end{array}$




\section{$1 \quad$ Introduction}

Anaerobic digestion of livestock waste is a waste management technology that can improve the quality of life for those in the developing world. Biogas produced from small-scale anaerobic digesters is most often used as a cooking fuel, but can also be used to heat water or buildings or generate electricity for on-site use [1]. Lack of proper livestock waste management leads to runoff of pollutants into surface waters and contamination of groundwater. Anaerobic digesters can assist in reducing water pollution by decreasing the concentration of organic matter in the waste. In addition, these systems can be a useful tool to mitigate deforestation when biogas is used as a cooking fuel rather than firewood. This also results in decreased public health concerns, especially for women and children who are disproportionally affected by indoor air pollution due to cultural and social roles [1]. The effluent from anaerobic digestion also contains primary nutrients (nitrogen, phosphorus) that can be used as a soil amendment to improve crop yields [1].

Polyethylene tubular anaerobic digesters are commonly used in household-scale applications to recover energy from livestock waste in the developing world. These systems do not require a high level of skilled labor to install; they are easy to operate, low in cost and can operate under a range of temperature conditions. Several studies have been carried out investigating the effect of influent waste characteristics and reactor design and operation on tubular digester performance $[1,2]$. However, no prior studies exist that combine mathematical modeling analyzing the physical (transport and mixing) and biochemical processes with field studies of tubular anaerobic digester performance.

Mathematical models have been used to provide insights into operating hydraulic residence time (HRT) and mean cell retention time (MCRT) in anaerobic digesters [3]. Control 
of HRT and MCRT are needed to avoid wash-out of soluble substrates and slow growing microorganisms, respectively [4]. Mixing mechanisms in digesters that can affect HRT include formation of dead zones, and short-circuiting/channeling (substrate by-passing treatment) [5]. In bioreactors without solids separation and recycling, MCRT is normally considered to be equal to the HRT; however, even without solids separation or recycling, the MCRT in tubular digesters may be longer than the HRT due to solids settling and accumulation [1,2]. Tubular digesters are fed with a high solids concentration, which favors collisions between particles to form flocs that are denser than water. Over time a floccular sludge layer forms, similar to processes occurring in anaerobic baffled and upflow anaerobic sludge blanket (UASB) reactors [6,7]. Hydrolysis of particulates into soluble substrates and formation of organic acids (intermediate substrates for methanogens) by acidogens are often considered the rate limiting steps during anaerobic digestion and are affected by the MCRT [4]. As the MCRT increases, hydrolyzing and acidogenic bacterial growth rates increase because they have adequate time to utilize solid and soluble substrates to form acetate and hydrogen $\left(\mathrm{H}_{2}\right)$, which are utilized by the methanogens [4]. Computational fluid dynamics (CFD) modeling is a useful tool that can produce residence time distribution (RTD) data for estimating the mean liquid HRT in a digester. CFD models have been successfully applied to contactors used for water and wastewater treatment [8, 31-33]. These models can also provide information on the physical mechanisms within the digester [3]. CFD models can be computationally expensive, and alternatively these models may be used to help validate or to inform simplified transport models, such as plug flow, completely mixed, tanks in series and or dispersion [9]. Several studies have been carried out using CFD to evaluate the effect of transport and mixing mechanisms on biogas production in completely 
mixed anaerobic digesters; however, more research is needed to understand the physical mechanisms contributing to tubular digester performance [3].

While CFD modeling is useful for evaluating the physical processes and liquid HRT in anaerobic digesters, these models do not evaluate the biological processes occurring in the digesters. The anaerobic digestion model 1 (ADM1) is a steady-state bioprocess model that incorporates hydrolysis and acidogenesis with influent and effluent characteristics to estimate volatile solids (VS) removal and methane $\left(\mathrm{CH}_{4}\right)$ production [10].The ADM1 model is complex, involving 19 process kinetics and 24 biochemical components to determine digester performance. In addition, ADM1 models the reactor as a completely stirred tank reactor (CSTR), which may not be appropriate for modeling the performance of tubular digesters with floccular sludge accumulation. To overcome this limitation, Bernard et al. [11] and Elmitwalli [12] developed simple models for anaerobic floccular sludge layer reactors. The models incorporate acidogenesis and methanogenesis and have been applied to full-scale UASB reactors [12].

This study investigated the performance (biogas production and effluent quality) of a tubular digester treating livestock waste in the Monteverde region of Costa Rica through experimental studies and combined CFD and bioprocess modeling. A tracer study was performed on this digester to gain insight into transport and mixing mechanisms in the system. A reduced order model was developed following a CFD simulation of a 24 hour cycle in the digester. The CFD simulation was also used to visualize transport and mixing mechanisms in the digester. Meanwhile the reduced order transport model was used to run over several 24 hour cycles in order to estimate the operating HRT. A simplified bioprocess model, incorporating conversion of soluble substrates to $\mathrm{CH}_{4}$ and biomass decay, was used to estimate the active biomass 
concentration in the digester. The active biomass concentration was used to estimate the operating MCRT. Results of the physical and biological process models provided a supporting framework on the relationship between the transport and transformation mechanisms and how these mechanisms affect biogas production and effluent quality in tubular digesters.

\section{$2 \quad$ Materials and Methods}

\subsection{Site Description and Tubular Digesters}

San Luis de Monteverde is a rural mountain community located on the Pacific slope of the Tilarán mountain chain in northwest region of Costa Rica with an altitude range of 600 to $1200 \mathrm{~m}(\sim 0.85 \mathrm{~atm})$ above sea level. San Luis has a population of approximately 500 people. The main economic activities in San Luis are small-scale production and sale of farm products, including coffee, vegetables, fruit, beans, corn, pork, beef, chicken and eggs; rural tourism is also significant. Households in San Luis have access to potable water provided by a locally administrated aqueduct project. Domestic wastewater is normally treated using septic systems, while livestock wastewater remains largely untreated causing contamination of the watershed. To improve livestock waste management, community leaders have obtained the support of local and international collaborators, such as the University of Georgia and the Monteverde Institute, to install tubular digesters in the San Luis valley.

Eight farmers in San Luis use Taiwanese-model tubular polypropylene bag digesters with PVC piping to treat livestock waste and produce biogas for cooking. The digesters have a 9-12 $\mathrm{m}^{3}$ working volume with a $4 \mathrm{~m}^{3}$ biogas storage bag. These household digesters typically treat swine waste from 4-10 pigs and provide fuel for approximately 4 hours of cooking per day, which meets the needs of an average family of 5 people. The operating parameters for the digester that was analyzed in this study, over a 5 week field-study are shown in Table 1. 


\subsection{Tracer study}

A tracer study was performed to understand the digester's transport and mixing behavior. It should be noted that this is the first study to perform a tracer study on a tubular digester to understand these system's hydrodynamic mechanisms. Fertilizer grade potassium chloride $(\mathrm{KCl})$ (Mezcla Distribuido, Limón Costa Rica) was used as a tracer due to its ease of use and lack of hazardous waste produced, as the effluent from the digester is used to fertilize cattle pastureland. A calibration curve was developed to allow effluent tracer conductivity measurements to be reported in terms of $\mathrm{KCl}$ concentration $(\mathrm{g} \mathrm{KCl} / \mathrm{L})$. The target influent concentration was $9.42 \mathrm{~g}$ $\mathrm{KCl} / \mathrm{L}$. This concentration was selected to ensure that the effluent conductivity was significantly higher than the measured background conductivity and that the chloride concentration did not inhibit methanogenesis [13]. Note that biogas production in the digester remained stable during the tracer study, as will be discussed later. A mass of $4.75 \mathrm{~kg}$ of $\mathrm{KCl}$ was added to the $572 \mathrm{~L}$ of influent, mixed thoroughly and quickly poured into the digester through the influent pipe. Samples were collected from the outlet pipe every other day for 32 days and conductivity was measured as described below.

\subsection{Analytical Methods}

All laboratory analyses were carried out at the University of Georgia Costa Rica campus (San Luis, Puntarenas, Costa Rica). Influent and effluent samples were collected and analyzed weekly from the digester for 5 weeks. Standard Methods [14] were used to measure $\mathrm{BOD}_{5}$ (5210), VS, and total solids (TS) (2540 G). Hach high range TNT test kits and a Hach DR 890 portable colorimeter (Loveland, CO) were used to measure total ammonia nitrogen (TAN) (TNT 832), total nitrogen (TN) (TNT 827) and total phosphorus (TP) (TNT 845) concentrations. pH was measured using Oakton portable waterproof pHTestr 10 (Vernon Hills, IL). COD 
measurements could not be carried out during the field-study because there were no facilities to dispose the hazardous waste generated. Biogas volume in the tubular digester was measured using a wet tip gas meter (Wayne, PA). $\mathrm{CH}_{4}$ content of the biogas was measured using RKI Eagle 72-5335RK-05 portable gas detector equipped with $\mathrm{CH}_{4}$ and $\mathrm{CO}_{2}$ sensors. Digester temperature was measured using a Thomas traceable digital thermometer (Philadelphia, PA). Conductivity was measured using a Fisher scientific traceable conductivity meter (Hanover Park, IL) with a conductivity detection limit of $19.99 \mathrm{mS} / \mathrm{m}$. Method detection limits (MDL) were (mg/L): TAN (2), TN (5) and TP (1.5). A sample of floccular sludge from the tubular digester was collected from the outlet pipe (Figure 1a). A $0.25 \mathrm{~L}$ container was securely taped to a $1.5 \mathrm{~m}$ tube and slowly introduced into the tubular digester from the outlet pipe. A sample volume of 5.0 L was collected and analyzed based on standard methods [14] for total suspended solids (TSS) (2540 D), volatile suspended solids (VSS) (2540 E) and sludge volume index (SVI) (2710 D).

\subsection{Data Analysis}

Oracle Crystal Ball (Redwood City, CA) was used for Monte Carlo simulation. A Monte Carlo uncertainty analysis was performed by running 1,000 trials with selected parameter values within the range previously reported in the literature (Table 2) to determine which model inputs affected the MCRT value predicted by the simplified bioprocess model developed. All the kinetic inputs to the bioprocess model were considered uncertain inputs with triangular distributions. Triangular distributions were used due to lack of sufficient kinetic input data to fit a uniform distribution. Crystal Ball calculates the sensitivity by ranking what inputs significantly correlate with the output while the simulation is running. If an input and output have a high correlation percentage, it means that the input will have a significant impact on the output. The percentage is the rank of correlations normalized to $100 \%$. A positive contribution means that the 
input will increase the output and a negative contribution means the input will decrease the output.

\section{$3 \quad$ Model Development}

\subsection{Physical Processes Modeling}

\subsubsection{Computational Fluid Dynamics: Governing Equations for Flow and Tracer Transport}

In this study, the unsteady Reynolds-averaged Navier-Stokes equations (RANS) simulation technique was employed for flow and tracer transport simulation in the tubular digester. In the present unsteady RANS simulation, the governing equations for flow and tracer transport were solved simultaneously at each time step. Governing equations for the flow consisted of the Reynolds-averaged continuity equation and incompressible Navier-Stokes equations:

$$
\begin{gathered}
\frac{\partial\left\langle u_{i}\right\rangle}{\partial x_{i}}=0 \\
\frac{\partial\left\langle u_{i}\right\rangle}{\partial t}+\left\langle u_{j}\right\rangle \frac{\partial\left\langle u_{i}\right\rangle}{\partial x_{j}}=-\frac{1}{\rho} \frac{\partial\langle p\rangle}{\partial x_{i}}+v \frac{\partial^{2}\left\langle u_{i}\right\rangle}{\partial x_{j}^{2}}-\frac{1}{\rho} \frac{\partial\left\langle u_{i}^{\prime} u_{j}^{\prime}\right\rangle}{\partial x_{j}}
\end{gathered}
$$

where a bracket denotes Reynolds-averaging, vector $\left\langle u_{i}\right\rangle$ is the Reynolds-averaged velocity, vector $x_{i}$ is position, $t$ is time, $\langle p\rangle$ is Reynolds-averaged pressure, $\rho$ is density, and $v$ is kinematic viscosity.

The Reynolds stress tensor $\left\langle u_{i}^{\prime} u_{j}^{\prime}\right\rangle$ (expressed in terms of velocity fluctuation $u_{i}^{\prime}$ ) was closed using an eddy viscosity model in which

$$
\left\langle u_{i}^{\prime} u_{j}^{\prime}\right\rangle=-\mu_{t} \frac{\partial\left\langle u_{i}\right\rangle}{\partial x_{j}}
$$

and the eddy viscosity is 


$$
\mu_{t}=C_{\mu} \frac{k^{2}}{\varepsilon}
$$

where $k$ is the turbulent kinetic energy and $\varepsilon$ is the turbulent kinetic energy dissipation rate.

Transport equations for $k$ and $\varepsilon$ were specified via the $k-\varepsilon$ model equipped with standard wall functions [15]. Model coefficient, $C_{\mu}$ was taken as $C_{\mu}=0.09$, its standard value.

Tracer transport was governed by the Reynolds-averaged advection-diffusion equation:

$$
\frac{\partial\langle C\rangle}{\partial t}+\left\langle u_{j}\right\rangle \frac{\partial\langle C\rangle}{\partial x_{j}}=-\frac{\partial\left\langle u_{i}^{\prime} C^{\prime}\right\rangle}{\partial x_{j}}
$$

where $\langle C\rangle$ is the ensemble-averaged tracer concentration, $C^{\prime}$ denotes tracer fluctuation and turbulent flux. $\left\langle u_{j}^{\prime} C^{\prime}\right\rangle$ was modeled as:

$$
-\left\langle u_{j}^{\prime} C^{\prime}\right\rangle=D_{t} \frac{\partial\langle C\rangle}{\partial x_{j}}
$$

Note that $\langle C\rangle$ is time-dependent due to transient boundary conditions, which are described below.

The eddy (turbulent) diffusivity was taken as $D_{t}=\frac{\mu_{t}}{\rho \cdot S c_{t}}$ where the eddy viscosity $\mu_{t}$, was computed via the $k-\varepsilon$ model and the turbulent Schmidt number, $S c_{t}$, was taken as 0.7 [16]. Note that in Eq. 5, molecular diffusivity has been neglected with respect to the turbulent diffusivity for reasons to be discussed further below.

It should be noted that in the present CFD simulation, the tubular digester's flexible walls, solids accumulation and biogas bubble generation were not considered. Although incorporating those features into the CFD model may make the CFD simulation more accurate and detailed, this additional complexity had no significant impacts on the primary function of the CFD model for this study, which was to validate the two assumptions that were used to develop the reduced order model (Section 3.1.3). 


\subsubsection{CFD Flow Set-Up}

The digester is $8 \mathrm{~m}$ long with a $1.59 \mathrm{~m}$-internal diameter; other digester dimensions and components are shown in Figure 1a. The computational domain is shown in Figure 1b. Based on our interviews with the farmers and participant observations [17], the normal operating procedure was that each day swine waste was mixed with water to obtain a slurry with an average TS concentration of $6.35 \mathrm{~g} / \mathrm{L}$. The slurry was fed into the digester for approximately 15 minutes at a rate of approximately $2,280 \mathrm{~L} / \mathrm{h}$. The Reynolds number was estimated to be 7,964 at the inlet zone based on inlet diameter $(0.1 \mathrm{~m})$ and influent velocity $(0.078 \mathrm{~m} / \mathrm{s})$, and 674 in the main digester based on the diameter of the digester $(1.59 \mathrm{~m})$ and bulk velocity $\left(4 \times 10^{-4} \mathrm{~m} / \mathrm{s}\right)$. The CFD numerical digester was run to simulate the first day of the physical tracer study. During the 15 minutes of feeding (flow-through) at the beginning of the 24-hour cycle, the inlet of the digester was assigned a constant influent velocity. A pressure outlet boundary condition was applied to the outlet of the digester. The other boundaries employed no-slip wall boundary conditions. After the 15-minute flow-through period ended, the flow into the digester was shut down and thus the digester behaved as a batch-reactor for the remainder of the simulation . During this stage the boundary conditions for the inlet and outlet changed to no-slip wall boundary conditions since the system was assumed to be closed. The other boundary conditions did not change.

To understand the general flow behavior and transport within the digester, a conservative tracer with a concentration $8.3 \mathrm{~g} \mathrm{KCl} / \mathrm{L}$ was injected into the digester during the initial feeding 15-minute flow-through period of the CFD simulation. This was calculated by dividing the total tracer mass $(4.75 \mathrm{~kg})$ by the influent flow $(572 \mathrm{~L})$ during the 15 minute flow-through period. Note that a CFD RTD could be generated based on the tracer transport but would require 
simulating the physical experiment for 32 days. This would increase computational cost and the projected computing period would take months. Instead, the reduced-order transport model developed in sub-section 3.1.3 was used to predict the RTD curve and a mean HRT.

An unstructured grid, which was generated using Gambit (Fluent, Inc. 2004), was employed for the physical processes model simulations. The total number of grid cells was 85,134. This mesh is shown over half of the domain in Figure 1b. All simulations were conducted using OpenFOAM (OpenCFD Ltd., 2012), a collection of C++ libraries for solving continuum mechanics problems using the well-known finite volume method.

\subsubsection{Reduced Order Transport Model}

A general mass balance equation for the system during the 15 minute flow-through period was written as

$$
V \frac{d C_{d}}{d t}=Q C_{\text {in }}-Q C_{\text {out }}
$$

where $C_{d}$ is the tracer concentration in the digester, $C_{i n}$ is the influent tracer concentration, $C_{\text {out }}$ is the effluent tracer concentration, $V$ is the volume of the digester, $Q$ is flow rate and $t$ is time. Based on the operating conditions, two assumptions were made. The first assumption was that the batch reactor period was sufficient to mix the tracer in the digester. Thus $C_{d}$ was uniform everywhere in the digester at the end of the batch reactor period or at the beginning of the next flow-through period.

$$
C_{o u t}^{n}=C_{d}^{(n-1)}
$$

where $n$ indicates current day and $(n-1)$ indicates the previous day.

The second assumption was that during the 15 minute flow-through period, the impact of

the inflow on the effluent concentration was negligible. That is $C_{o u t}^{n}=C_{d}^{(n-1)}$ was valid for all of 
the flow-through periods. The two assumptions were subsequently validated via CFD simulations. By applying the two assumptions, Equation 7 was integrated and expressed as:

$$
C_{d}^{n}=C_{d}^{n-1}+\frac{T Q}{V}\left(C_{i n}^{n}-C_{d}^{(n-1)}\right)
$$

with conditions:

$$
\begin{gathered}
C_{d}^{0}=0 \\
C_{i n}^{n}=\left\{\begin{array}{cc}
C_{0} & n=0 \\
0 & n \geq 1
\end{array}\right.
\end{gathered}
$$

where $C_{0}$ is the initial tracer concentration in the digester and $T$ is the 15 minute flow-through period.

\subsection{Bioprocess Model}

Since floccular and granular sludge reactors, such as anaerobic baffled and UASB reactors, have been used to treat high strength swine waste [6,7], the bioprocess model was based on a granular sludge reactor model developed by Elmitwalli [12]. Given that the active biomass concentrations inside the tubular digester $\left(X_{m}\right)$ and in the effluent $\left(X_{m e}\right)$ were unknown, the bioprocess model was used to calculate these values, which were used to estimate the MCRT according to the following:

$$
M C R T=\frac{V X_{m}}{Q X_{m e}}
$$

The full bioprocess model formulation is presented in Elmitwalli [12]. Mass balances on $X_{m}$ and daily methane production rate ( $\dot{\mathrm{m}})$ were sufficient to estimate the MCRT for this study, so only these equations are presented here. A steady-state mass balance on $X_{m}$ in the digester yields:

$$
0=Q X_{m i}-Q X_{m e}+Y_{m} \frac{K_{m} S_{b} X_{m}}{K_{S}+S_{b}} V-K_{d} X_{m} V
$$


where $X_{m i}$ is the active biomass in the influent (assumed to be negligible), $S_{b}$ is the soluble biodegradable substrate concentration (assumed to be equal to the effluent $\mathrm{BOD}_{5}$ concentration), $K_{S}$ is the biomass half saturation constant and $K_{m}$ is the Monod maximum substrate utilization rate. A steady-state mass balance on $\mathrm{CH}_{4}$ in the system yields:

$$
0=-\dot{\mathrm{m}}+\left(1-Y_{m}\right) \frac{K_{m} S_{b} X_{m}}{K_{S}+S_{b}} V
$$

where $\dot{m}$ is the daily methane production rate. Note that the daily methane production rate was expressed as g COD/day by adjusting the measured methane production rates (Table 2) to standard temperature and pressure (STP) and assuming $4 \mathrm{~g} \mathrm{COD} / \mathrm{g} \mathrm{CH}_{4}$. The kinetic constants that were applied to this model were obtained from studies treating swine waste at psychrophilic temperatures (Table 2). A Monte Carlo uncertainty analysis was performed as described in section 2.4 to determine how the kinetic inputs affected the MCRT value.

\section{$4 \quad$ Results and Discussion}

\subsection{Overall Tubular Digester Performance}

Average performance of the tubular digester over the 5-week field study period is shown in Table 3. The TSS and VSS concentrations retrieved from the sludge settleability analysis were $33.2 \mathrm{~g} \mathrm{TSS} / \mathrm{L}$ and $0.40 \mathrm{~g}$ VSS/L respectively and sludge had a SVI of $1.51 \mathrm{~mL} / \mathrm{g}$ TSS. From these results, three main conclusions can be drawn.

First, the results from the settleability analysis indicate that the sludge retrieved from within the tubular digester had good settling characteristics. Sludge with a SVI below $10 \mathrm{~mL} / \mathrm{g}$ TSS is considered to have good settling properties, which is characteristic of floccular sludge flocs [20]. Having biologically active floccular sludge with a low SVI has shown to improve $\mathrm{CH}_{4}$ production in an anaerobic sequencing batch reactor treating swine waste [20]. Immobilization of methanogens and other anaerobic digestion microorganisms onto inert material and other cells to 
form granules is beneficial because this promotes diversity in the microbial community. This is due to metabolic interactions within the granule that promote faster substrate utilization. Formation of granules also promotes a more flexible and stable sludge that can withstand temperature and loading rate fluctuations [21]. Although the floccular sludge in the tubular digester is compared to granular sludge due to similarities in the sludge properties, low SVI and long MCRT without the presence of biofilm carriers, characteristic granules were not observed in the tubular digester contents. Since good $\mathrm{CH}_{4}$ production was observed in the tubular digester, the low VSS concentration from the solids settleability test indicated that the microbial composition of the sludge changes diagonally within the tubular digester. This observation was in good agreement with Montteran et al. [7] who showed diagonal distinction in the microbial composition of granules from an anaerobic baffled reactor treating swine waste. Each diagonal compartment contained separate microbial groups representing each anaerobic digestion phase (fermentation, acidogenesis, acetogenesis and methanogenesis). Due to the design of the tubular digester, it was not feasible to collect samples other than from the outlet pipe. The low VSS to TSS ratio indicated that the sludge taken from the outlet pipe was mainly inert material. This was likely influenced by the MCRT. Longer MCRT allow for greater degradation of the organic matter in the influent. Results from the biological model used to estimate the MCRT are discussed later.

The second main conclusion is that the digester had high VS and $\mathrm{BOD}_{5}$ removal efficiencies (Table 3). The ability for anaerobic digestion to decrease the organic matter concentration in waste is one of its attractive benefits. The $\mathrm{VS}$ and $\mathrm{BOD}_{5}$ removal efficiencies were greater than $75 \%$. This is greater than previously reported values for complete mix digesters treating swine waste at mesophilic and thermophilic temperatures [4, 22]. These high 
organic matter removal rates provided further evidence of solids accumulation and formation of a biologically active floccular sludge layer.

The third main conclusion is that high TN and TP percent removals were observed; 83.6 and $91.6 \%$ respectively. Since there is no removal mechanism for TN and TP during anaerobic digestion, other processes were investigated to better understand TN and TP removal mechanisms. During anaerobic digestion, nitrogen, phosphorus and metal ions present in the organic matter are released as particulate organic matter is degraded. Swine waste contains high concentrations of magnesium $(\mathrm{Mg}), \mathrm{TN}$ and $\mathrm{TP}$, which may lead to the formation of struvite $\left(\mathrm{MgNH}_{4} \mathrm{PO}_{4} \cdot 6 \mathrm{H}_{2} \mathrm{O}\right)$, which can attach to solids within the reactor. Struvite precipitates can be an operational problem because they cause pumps to foul and pipe blockage [23]. Struvite precipitation during anaerobic digestion is affected by $\mathrm{pH}$, rate of mixing, temperature, solids settleability and ion molar ratios [23]. To assess whether conditions in the tubular digester favored struvite precipitation, the thermodynamic solubility product of $\left[\mathrm{Mg}^{2+}\right]\left[\mathrm{NH}_{4}^{+}\right]\left[\mathrm{PO}_{4}{ }^{3-}\right]$ was analyzed [24]. Influent $\mathrm{Mg}$ concentration was assumed to be $0.21 \mathrm{~g} / \mathrm{L}$ based on an average value from prior studies of swine waste characteristics (see Lin [25] for review). A thermodynamic solubility product $\left(\log \mathrm{K}_{\mathrm{sp}}\right)$ of $10^{-11.4}$ was estimated, which was within the struvite solubility product of $10^{-9.41}-10^{-14.1}$ at $20-25^{\circ} \mathrm{C}$ and a $\mathrm{pH}$ of $6.45-8.97$ [24]. Thermodynamic solubility products within this range indicate struvite precipitation within the digester was favored. Tubular digesters may require periodical desludging every 5-10 years due to the solids accumulation [26] and the sludge can be expected to have a high TP concentration.

\subsection{CFD and Reduced Order Transport Model}

Unsteady RANS simulations were conducted for the first day after releasing the tracer for the 15 minute flow-through period and the subsequent 23 hours and 45 minutes batch-reactor 
period. For the 15 minute flow-through period, there was flow spanning the entire digester from the inlet through the outlet. Following the coordinate system established in Figure 1b, speed contours on the middle $\mathrm{x}-\mathrm{z}$ plane and three $\mathrm{y}$-z planes (at $\mathrm{x}=0,4$, and $8 \mathrm{~m}$ respectively) for 1,5 , 10 and 15 minutes are shown in Figure 2 a-d respectively. From Figure 2, it was observed that the flow developed during the first 5 minutes and unsteady flow behavior was observed at the tail of the high-speed jet (red color) after 5 minutes (Figure $2 \mathrm{~b}, \mathrm{c}$ and d). Areas within the digester with short circuiting and dead zones were also observed and are reflected in the streamline and velocity vector distribution shown in Figure $2 \mathrm{e}$ and $\mathrm{f}$. Tracer concentration contours on the middle $\mathrm{x}-\mathrm{z}$ plane and three $\mathrm{y}-\mathrm{z}$ planes (at $\mathrm{x}=0,4$, and $8 \mathrm{~m}$ respectively) for $1,5,10$ and 15 minutes are shown in Figure 3 a-d respectively. From Figure 3d, it can be seen that the tracer moves quickly through the digester due to the short-circuiting pathway but does not reach the digester outlet by the end of the 15 minute flow-through period. The simulation predicted an outlet tracer concentration less than $1 \times 10^{-30} \mathrm{~g} \mathrm{KCl} / \mathrm{L}$ at the end of the 15 minute flow-through period. This demonstrated that the influent flow had negligible effect on the effluent concentration and serves to validate the second assumption in the reduced-order transport model developed in sub-section 3.1.2.

During the 23 hours and 45 minutes batch-reactor period there is no flow at the inlet or outlet. The speed contours in the middle $\mathrm{x}-\mathrm{z}$ plane and three $\mathrm{y}-\mathrm{z}$ planes $(\mathrm{x}=0,4$, and $8 \mathrm{~m})$ at 15 and 30 minutes and 1, 3, 6 and 24 hours after batch-mode initiation are shown in Figure 4a-f. From Figure 4, it was observed that although there was no flow through the inlet or outlet, flow continued within the digester. The tracer continued to move towards the outlet of the digester due to inertia, resulting in tracer transport during the first hour after the system was closed (Figure $4 \mathrm{a}, \mathrm{b}$, and c). The flow gradually slowed down due to viscosity, after which the main tracer 
transport mechanism was by turbulent diffusion. The tracer concentration contour had insignificant change after one hour because transport via turbulent diffusion is slower than that by advection (Figure 4d, e, and f).

It should be noted that turbulence started to decay once the system was closed and batch mode was initiated. However residual turbulence took a long time to dissipate (data not shown). For example, there was still residual motion at $\mathrm{t}=15$ hours and 24 hours and the turbulent viscosity in most places remained significant $\left(>6 \times 10^{-6} \mathrm{~m}^{2} / \mathrm{s}\right)$, making the turbulent diffusivity (which was calculated as the turbulent viscosity divided by the turbulent Schmidt number (0.7)) to be much greater than the molecular diffusivity of the tracer $(\mathrm{KCl}), 2.47 \times 10^{-9} \mathrm{~m}^{2} / \mathrm{s}$. Therefore, it was acceptable to neglect molecular diffusivity in the simulations, as evidenced through Eq. 5 . In the physical system it would be expected that the turbulent diffusivity could be even be greater than that predicted by the CFD because the mechanism of biogas generation, which occurs during the batch period and may generate turbulence, was not considered in the CFD model.

At the end of the 23 hours and 45 minutes CFD-simulated batch-reactor period, the tracer concentration was evenly distributed in the digester except for the area near the inlet. The effluent tracer concentration from the experimental data was $0.51 \mathrm{~g} \mathrm{KCl} / \mathrm{L}$, which was $27 \%$ higher than the reduced-order model prediction $(0.4 \mathrm{~g} \mathrm{KCl} / \mathrm{L})$. In anaerobic digesters, biogas bubbles generated provide some mixing in the system. However, mixing from biogas bubbles was not considered during the unsteady RANS simulations as mentioned above. If it was considered, the tracer in the digester would be closer to completely mixed. Thus, the CFD simulation results for the tracer transport during the 23 hours and 45 minutes batch-reactor period support the first assumption of the reduced-order transport model that the system 
functions as a CSTR during this period. Further corroborating of this assumption is that the experimental RTD curve (Figure 5a) is characteristic of a CSTR mixing mechanism [5].

Although considering non-Newtonian fluids may have made the simulation more accurate, this consideration may have had a minor impact on the validation of the two assumptions. First, if we were to consider non-Newtonian behavior, the second assumption that during the flow-through period, the impact of the inflow on the effluent concentration was negligible would remain valid since the non-Newtonian behavior would result in a more sluggish flow toward the outlet. Second, since our first assumption was that the batch reactor period was sufficient to mix the tracer in the digester; non-Newtonian behavior may weaken turbulent mixing. However, this could be offset by biogas generation, which was not included in the model and is known to increase mixing. Thus we believe the first assumption was still valid even though both non-Newtonian behavior and biogas generation were not considered in the CFD model.

After validating the first and second assumptions through the unsteady RANS CFD simulation, the RTD was predicted using the reduced order model. The model RTD was compared to the experimental data in Figure 5a and b. From Figure 5b the predicted RTD was in good agreement with the experimental RTD, with a coefficient of determination, denoted $\mathrm{R}^{2}$, of 0.874. The mean liquid HRT predicted from the reduced-order model was 22.8 days. Note that in principle the CFD simulations could have been used to obtain the mean liquid HRT, but this would require running the simulation for much longer than 24 hours, thereby making the simulation very expensive. Instead, for computational efficiency the CFD was used to validate the assumptions behind the reduced order model which is less expensive than the CFD for predicting HRT. 


\subsection{Bioprocess Model}

Results for range of $X_{m}, X_{m e}, \mathrm{MCRT}$ and $\mathrm{CH}_{4}$ activity values are shown in Table 4 . An average MCRT of 115 days was estimated with a median of 110 days, minimum of 52 days, maximum of 265 days and a standard deviation of 33.6. It should be noted that the modeled $X_{m e}$ concentration was within the range of the measured effluent VS concentrations (Table 3). A Monte Carlo sensitivity analyses (as described in Section 2.4) was carried out to determine which bioprocess kinetic inputs significantly influenced the MCRT and the probability distribution of the MCRT. The outcomes from the simulation are graphically represented in Figure 6. From these results, two main conclusions can be drawn.

First, the performance and MCRT values obtained from this study were similar to other studies using floccular sludge layer reactors to treat wastewater at psychrophilic temperatures. Lim and Fox [27] reported organic matter removal rates of approximately $90 \%$ when treating swine waste in UASB reactors at psychrophilic temperatures. Uemura and Harada [28] obtained MCRTs ranging from 110 to 117 days and $\mathrm{CH}_{4}$ activity of 0.03-0.09 $\mathrm{g} \mathrm{CH}_{4}-\mathrm{COD} / \mathrm{g} \mathrm{VS}$ added-day while treating domestic wastewater in a UASB at 13 to $25^{\circ} \mathrm{C}$. These results are similar to the results from the tubular digesters in this study (Table 4) and also in agreement with Henze et al. [29], who recommended an MCRT of 60-140 days while treating domestic wastewater at 15$25^{\circ} \mathrm{C}$ in a floccular sludge layer reactor. Although the recommended values are for domestic wastewater, they are a useful starting point due to limited literature on MCRT in tubular and floccular sludge layer reactors treating swine waste.

Second, the MCRT value was most sensitive to $K_{m}, K_{d}$ and $K s$ and least sensitive to $Y_{m}$ (Figure 6). $K_{m}$ represents the maximum rate at which the active biomass can hydrolyze the particulate substrates. An increase in $K_{m}$ indicates that a shorter MCRT would be needed for the 
observed biogas production rate. $K_{d}$ is that rate at which the active biomass undergoes endogenous decay, resulting in a decrease in the active biomass in the digester. $K_{S}$ is the substrate concentration at which the anaerobic processes occur at half the biomass maximum growth rate and is an indicator of the active biomass affinity for substrate [30]. A decrease in $K_{S}$ indicates an increase the microbes' affinity for the substrate, thus indicating that a shorter MCRT is sufficient for hydrolysis and conversion the particulate and soluble substrates to $\mathrm{CH}_{4}$.

In tubular digesters, the physical and biological processes are interconnected. A sufficient mean liquid HRT is needed to allow for the solubilization of complex organic matter in the influent and to provide adequate contact time between the active floccular sludge layer and the dissolved substrates for efficient biogas production. A decrease in HRT reduces the contact time between the active floccular sludge layer and the dissolved substrates resulting in decreased biogas production. From the influent and effluent characteristics, sludge settleability and $\mathrm{CH}_{4}$ production rates observed in the tubular digester, a mean liquid HRT of 23 days combined with a MCRT of 115 days indicates a robust syntrophic relationship between the physical and biological processes. This good relationship led to low organic matter in the effluent and sufficient biogas production to meet households' energy demands. Although the effluent quality in the tubular digester was good in terms of organic matter, more research is needed to determine how the physical and biological processes affect other effluent characteristics such as pathogen concentrations, and how the CFD model can be used in combination with pathogen die off models to predict pathogen removal efficiencies. This is an important public health task because effluents from tubular digesters are often used as a soil amendment on food crops to reduce cost of purchasing mineral fertilizers. 


\section{Acknowledgements}

The authors acknowledge the Monteverde Institute and University of Georgia Costa Rica

for their assistance with this research. The authors also acknowledge the use of the services provided by Research Computing at the University of South Florida. This research was supported by the National Science Foundation under grant number 1243510 and USF Graduate School Signature Research Fellowship. Any opinions, findings, and conclusions or recommendations expressed in this material are those of the authors and do not necessarily reflect the views of the funding agencies. 


\section{References}

[1] Ferrer, I., Garfí, M., Uggetti, E., Ferrer-Martí, L., Calderon, A., Velo, E. Biogas production in low-cost household digesters at the Peruvian Andes. Biomass and Bioenergy, 35: 1668-1674 (2011). doi:10.1016/j.biombioe.2010.12.036

[2] Lansing, S., Martin, J. F., Botero, R. B., da Silva, T. N., da Silva, E. D. Methane production in low-cost, unheated, plug-flow digesters treating swine manure and used cooking grease. Bioresource Technology, 101 (12): 4362-70 (2010). doi:10.1016/j.biortech.2010.01.100

[3] Wu, B. Integration of mixing, heat transfer, and biochemical reaction kinetics in anaerobic methane fermentation. Biotechnology and Bioengineering, 109 (11): 2864-2874 (2012). doi:10.1002/bit.2455

[4] Kinyua, M.N., Cunningham, J., Ergas, S.J. Effect of Solids Retention Time on the Use of Anaerobically Digested Swine Waste as a Substrate for Denitrification, Bioresource Technology, 162: 14-20 (2014). doi: 10.1016/j.biortech.2014.03.111

[5] Levenspiel, O. Chemical Reaction Engineering (3rd ed.). John Wiley \& Sons, Hoboken, NJ (1999).

[6] Angelidaki, I., Ahring, B.K., Deng, H., Schmidt, J.E. Anaerobic digestion of olive mill effluents together with swine manure in UASB reactors. Water Science and Technology, 45 (10): 213-218 (2002).

[7] Montteran, F., Pereira, E.L., Campos, C.M.M. The behavior of anaerobic baffled reactor $(\mathrm{ABR})$ as the first stage in the biological treatment of hog farming effluent. Braz. J. Chem. Eng., 30 (2): 299-310 (2013). doi: http://dx.doi.org/10.1590/S0104-66322013000200008

[8] Zhang, J., Tejada-Martínez, A. E., Zhang, Q. Hydraulic Efficiency in RANS of the Flow in Multichambered Contactors. Journal of Hydraulic Engineering, 139 (11), 1150-1157 (2013). doi:10.1061/(ASCE)HY.1943-7900.0000777

[9] Méndez-Romero, D.C., López-López, A., Vallejo-Rodríguez, R., León-Becerril, E. Hydrodynamic and kinetic assessment of an anaerobic fixed-bed reactor for slaughterhouse 
wastewater treatment. Chemical Engineering and Processing: Process Intensification, 50: 273280 (2011). doi:10.1016/j.cep.2011.02.002

[10] Batstone, D.J., Keller, J., Angelidaki, I., Kalyuzhnyi, S.V., Pavlostathis, S.G., Rozzi, A., Sanders, W.T.N., Siegrist, H., Vavilin, V.A. Anaerobic Digestion Model No 1, Scientific and Technical Report (STR) No 13. International Water Association, London, UK, (2002).

[11] Bernard, O., Hajd-Sadok, Z., Dochain, D., Genovesi, A., Steyer, J.P. Dynamical model development and parameter identification for an anaerobic wastewater treatment process. Biotechnology and Bioengineering, 75 (4): 424-438 (2001). doi: 10.1002/bit.10036

[12] Elmitwalli, T. Mathematical modeling of upflow anaerobic sludge blanket (UASB) reactor treating domestic wastewater. Water Science \& Technology, 67(1): 24-32 (2013). doi: 10.2166/wst.2012.512.

[13] Serrano, A., Siles, J.A., Gutierrez, M.C. Martin, M.A. Optimization of anaerobic codigestion of strawberry and fish waste. Applied Biochemical Biotechnology, 173: 1391-1404 (2014). doi: 10.1007/s12010-014-0942-y

[14] APHA. Standard methods for the examination of water and wastewater (32nd ed.). American Public Health Association, Washington, DC, (2012).

[15] Wilcox, D.C. Turbulence modeling for CFD. DCW Industries, La Cañada, CA, (1994). [16] Launder, B.E. Heat and mass transport, in Chapter 6, Turbulence, P. Bradshaw editor, Springer-Verlag Series on Topics in Applied Physics, 12, 228-331 (1978).

[17] Kinyua, M.N. Energy production and effluent quality in tubular digesters treating livestock waste in rural Costa Rica. 2015. (Doctorate dissertation). University of South Florida, Tampa, FL.

[18] Massé, D.I., Droste, R.L. Comprehensive model of anaerobic digestion of swine manure in a sequencing batch reactor. Water Research, 34 (12): 3087-3106 (2000). doi:10.1016/S00431354(00)00064-6 
[19] Vavilin, V.A., Lokshina, L.Y., Rytov,S.V., Kotsyurbenko, O.R., Nozhevnikova, A.N., Parshina, S.N. Modeling methanogenesis during anaerobic conversion of complex organic matter at low temperatures. Water Science and Technology, 36 (6-7), 531-538 (1997).

[20] Angenent, L.T., Sung, S., Raskin, L. Methane yield and methanogen levels of ASBR systems treating swine waste: Effect of different inocula. VII Latin American Workshop and Symposium on Anaerobic Digestion (LAAD2002), Mérida, Yicatán, Mexico, International Water Association, London, UK, (2002).

[21] Bialek, K., Kumar, A., Mahony, T., Lens, P.N.L., Flaherty, V.O. Microbial community structure and dynamics in anaerobic fluidized-bed and granular sludge-bed reactors: influence of operational temperature and reactor configuration. Microbial Biotechnology, 5 (6): 738-752 (2012). doi:10.1111/j.1751-7915.2012.00364.x

[22] Hill, D.T., Bolte, J.P., Prince, T.J. Thermophilic anaerobic digestion of screened-flushed swine waste. Transactions of the ASABE, 29 (1): 229-234 (1986). doi: 10.13031/2013.30131

[23] Martí, N., Bouzas, A., Seco, A., Ferrer, J. Struvite precipitation assessment in anaerobic digestion processes. Chemical Engineering Journal, 141 (1-3): 67-74 (2008).

doi:10.1016/j.cej.2007.10.023

[24] Rahaman, M.S., Mavinic, D.S., Bhuiyan, M.I.H., Koch, F.A. Exploring the Determination of Struvite Solubility Product from Analytical Results. Environmental Technology, 27 (9): 951961 (2006).

[25] Lin, A.Y. Precipitation of Phosphate Minerals from Effluent of Anaerobically Digested Swine Manure (Masters' thesis). University of South Florida, Tampa, FL. (2012)

[26] Vögeli Y, Lohri CR, Gallardo A, Diener S, Christian S. Anaerobic Digestion of Biowaste in Developing Countries: Practical Information and Case Studies. Swiss Federal Institute of Aquatic Science and Technology (Eawag), Dübendorf, Switzerland, (2014).

[27] Lim, S.J., Fox, P. A kinetic evaluation of anaerobic treatment of swine wastewater at two temperatures in a temperate climate zone. Bioresource Technology, 102 (4): 3724-3729 (2011). doi:10.1016/j.biortech.2010.11.113 
[28] Uemura, S., Harada, H. Treatment of sewage by a UASB reactor under moderate to low temperature conditions. Bioresource Technology, 77: 275-282 (2000). PII: S0960-

8524(99)00118-2

[29] Henze, M., van Loosdrecht, M., Ekama,G., Brdjanovic, D. Biological Wastewater

Treatment: Principles, Modeling and Design. IWA Publishing, London, UK (2008).

[30] Metcalf \& Eddy., Tchobanoglous, G., Burton, F. L. 1., Stensel, H. D. Wastewater engineering: Treatment and reuse (4th ed). McGraw-Hill, Boston (2003).

[31] Zhang, J., Tejada-Martínez, A. E., Zhang, Q. RANS Simulation of the Flow and Tracer Transport in a Multi-chambered Ozone Contactor, Journal of Environmental Engineering, 139(3), 450-454 (2013). doi:10.1061/(ASCE)EE.1943-7870.0000648

[32] Zhang, J., Tejada-Martínez, A. E., Zhang, Q., Lei, H. Evaluating Hydraulic and Disinfection Efficiencies of a Full-Scale Ozone Contactor using a RANS-based Modeling Framework, Water Research, 52, 155-167 (2014). doi:10.1016/j.watres.2013.12.037

[33] Zhang, J., Tejada-Martínez, A. E., Zhang, Q. Developments in Computational Fluid Dynamics-Based Modeling Framework for Disinfection Technologies in Last Recent Two Decades: A Review, Environmental Software \& Modeling, 58, 71-85 (2014). doi:10.1016/j.envsoft.2014.04.003 
Table 1: Tubular digester operating parameters $(n=5)$.

\begin{tabular}{|c|c|c|}
\hline Parameter & Unit & Tubular Digester \\
\hline Working volume (V) & $\mathrm{L}_{\mathrm{d}}$ & 12000 \\
\hline Temperature & ${ }^{\circ} \mathrm{C}$ & $20.7 \pm 0.48$ \\
\hline Influent flow (Q) & L/day & $543 \pm 10.0$ \\
\hline OLR & g VS ${ }_{\text {added }} / \mathrm{L}_{\mathrm{d}}$-day & $0.26 \pm 0.10$ \\
\hline
\end{tabular}


Table 2: Kinetic constants applied in the bioprocess model.

\begin{tabular}{|l|l|c|c|l|}
\hline Parameter & \multicolumn{1}{|c|}{ Unit } & Minimum & Maximum & Reference \\
\hline$K_{d}$ & day $^{-1}$ & 0.006 & 0.04 & {$[18]$} \\
\hline$Y_{m}$ & $\begin{array}{l}\text { g biomass COD/g } \\
\text { COD utilized }\end{array}$ & 0.23 & 0.25 & {$[18]$} \\
\hline$K_{m}$ & $\begin{array}{l}\text { g COD utilized/g } \\
\text { biomass COD-day }\end{array}$ & 2.00 & 8.00 & {$[19]$} \\
\hline$K_{S}$ & g/L & 0.15 & 1.81 & {$[18,19]$} \\
\hline
\end{tabular}


Table 3: Average tubular digester influent and effluent characteristics $(n=5)$.

\begin{tabular}{cccc}
\hline Parameter & Unit & Influent & Effluent \\
\hline $\mathrm{BOD}_{5}$ & $\mathrm{~g} / \mathrm{L}$ & $5.09 \pm 0.30$ & $0.030 \pm 0.015$ \\
$\mathrm{TS}$ & $\mathrm{g} \mathrm{TS} / \mathrm{L}$ & $6.35 \pm 2.87$ & $0.77 \pm 0.25$ \\
$\mathrm{gS}$ & $\mathrm{g} \mathrm{VS} / \mathrm{L}$ & $5.17 \pm 2.44$ & $0.58 \pm 0.24$ \\
$\mathrm{TAN}$ & $\mathrm{mg} \mathrm{NH}_{4}^{+}-\mathrm{N} / \mathrm{L}$ & $140 \pm 49.0$ & $52.8 \pm 4.66$ \\
$\mathrm{TN}$ & $\mathrm{mg} \mathrm{N} / \mathrm{L}$ & $300 \pm 23.6$ & $49.3 \pm 5.12$ \\
$\mathrm{TP}$ & $\mathrm{mg} \mathrm{PO}_{4} / \mathrm{L}$ & $402 \pm 126$ & $33.9 \pm 8.91$ \\
$\mathrm{pH}$ & & $7.08 \pm 0.62$ & $7.04 \pm 0.14$ \\
$\mathrm{CH}_{4}$ production rate $(\dot{\mathrm{m}})$ & $\mathrm{m}^{3} \mathrm{CH}_{4} /$ day & \multicolumn{2}{c}{$2.01 \pm 0.87$} \\
\hline
\end{tabular}


Table 4: Bioprocess model results and calculated $\mathrm{CH}_{4}$ activity.

\begin{tabular}{llc}
\hline Parameter & Unit & Value \\
\hline$X_{m}$ & g COD/L & $2.00-4.94$ \\
$X_{m e}$ & $\mathrm{~g} \mathrm{COD} / \mathrm{L}$ & $0.34-1.03$ \\
$\mathrm{MCRT}$ & day & $51-259$ \\
$\mathrm{CH}_{4}$ activity & $\mathrm{g} \mathrm{CH}_{4}-\mathrm{COD} / \mathrm{g} \mathrm{VS}_{\text {added-day }}$ & $0.056-0.086$ \\
\hline
\end{tabular}




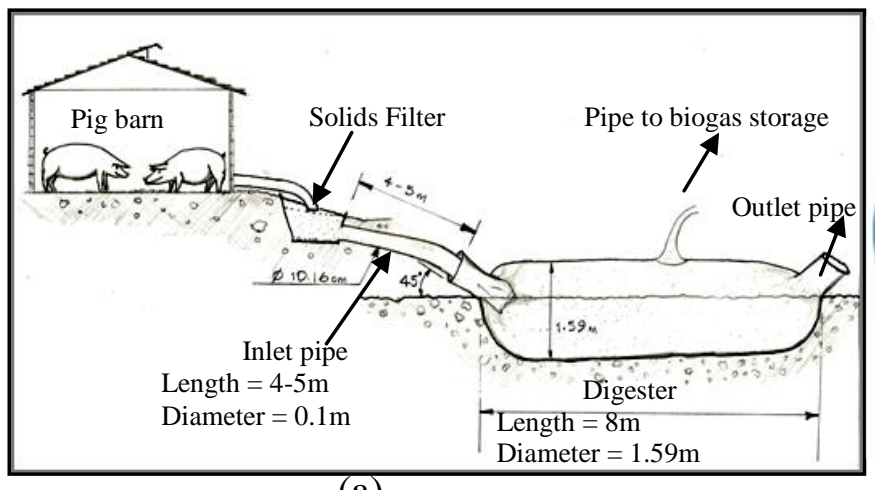

(a)

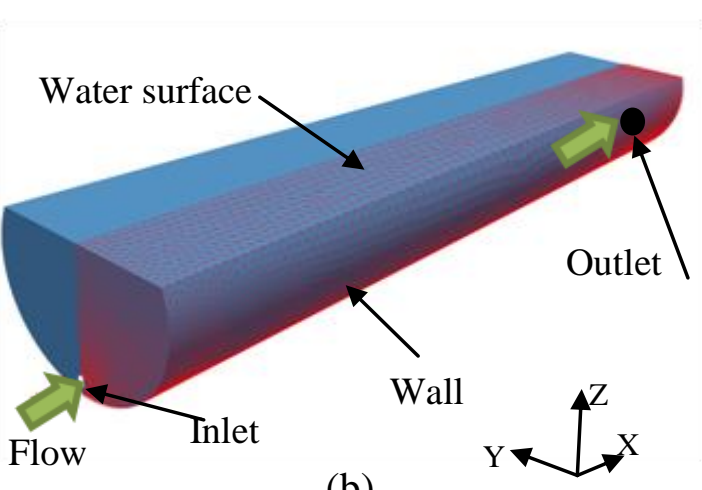

(b)

Figure 1:(a) Schematic and (b) CFD domain and grid of the tubular digester 

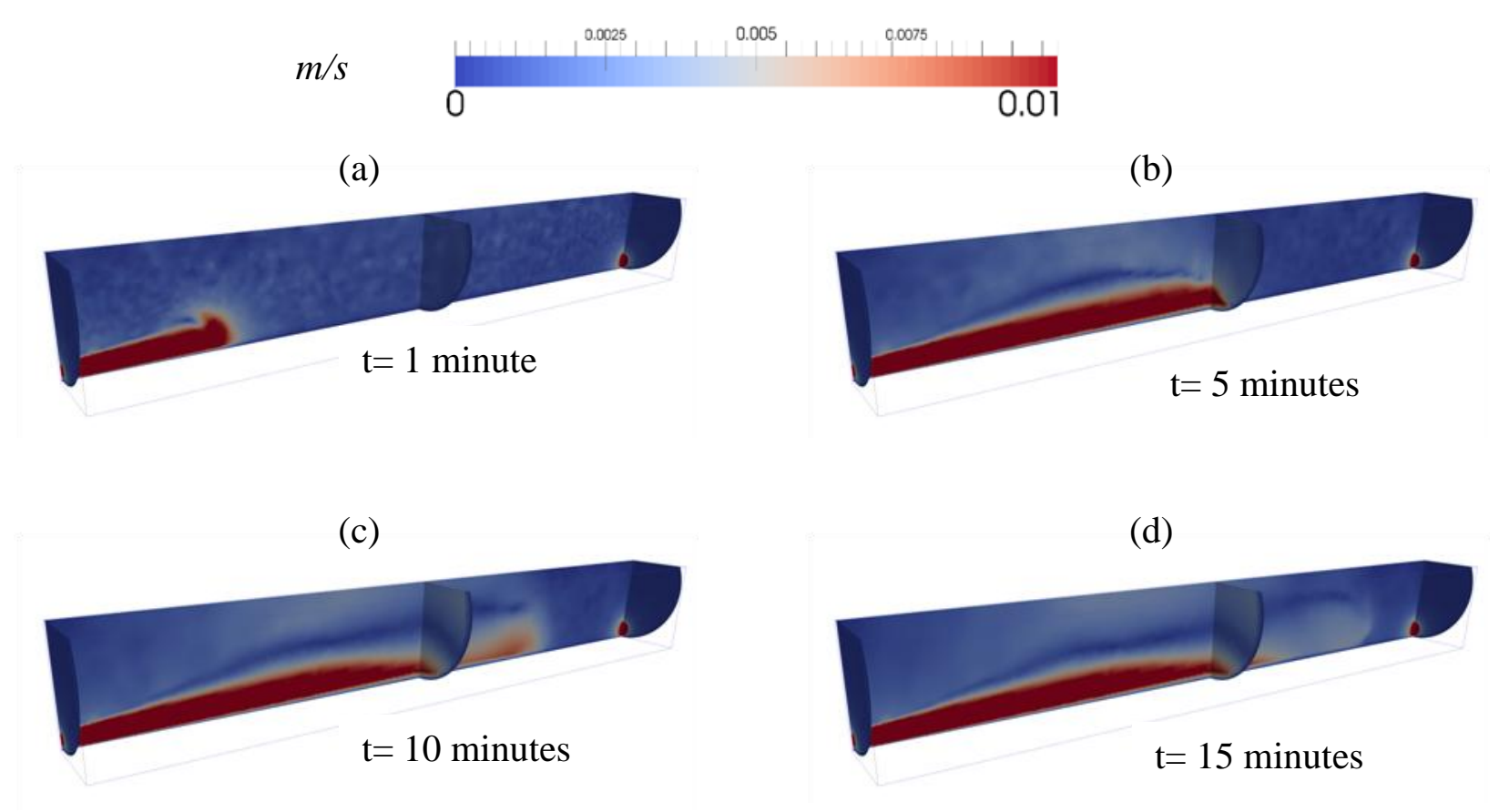

(e)

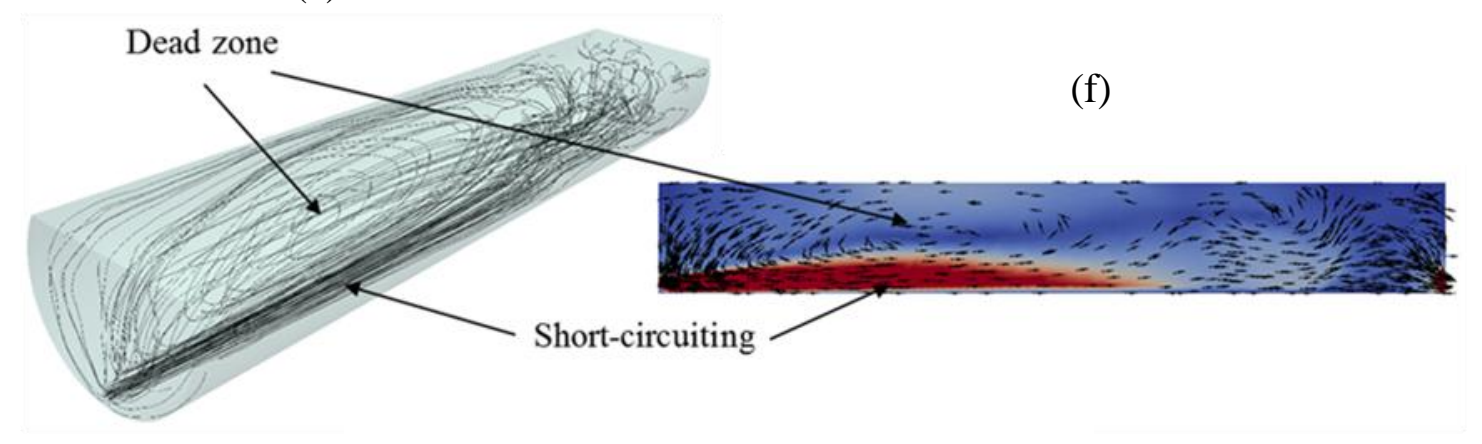

Figure 2:(a-d) Contour of speed (flow pattern) at various times on middle x-z plane and three y$\mathrm{z}$ planes $(\mathrm{x}=0,4$, and $8 \mathrm{~m}),(\mathrm{e})$ streamline of flow in the digester and (f) velocity vector distribution on middle $\mathrm{x}-\mathrm{z}$ planes 


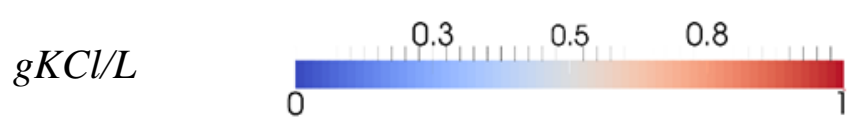

(a)

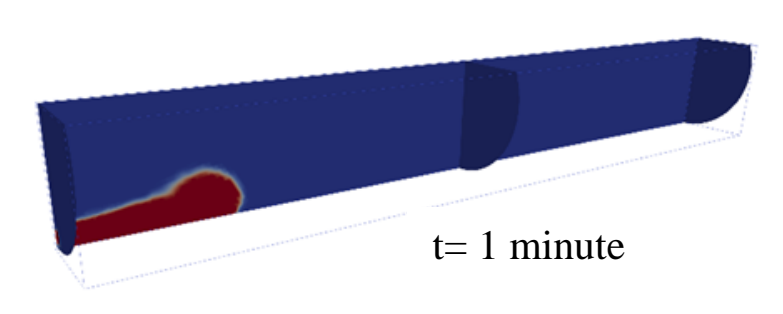

(c)

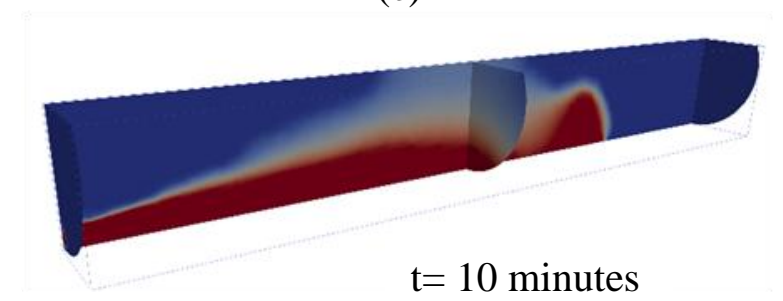

(b)

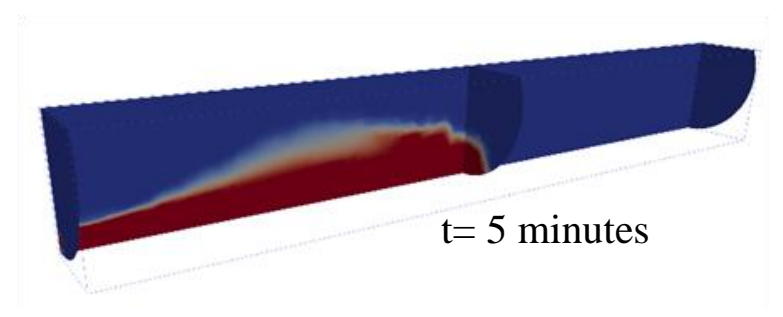

(d)

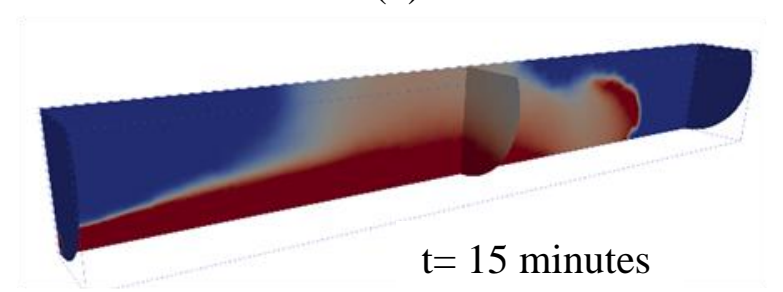

Figure 3: Contour of tracer concentration (tracer distribution) for the 15 minute flow-through period on middle $\mathrm{x}-\mathrm{z}$ plane and three $\mathrm{y}-\mathrm{z}$ planes $(\mathrm{x}=0,4$, and $8 \mathrm{~m})$ 
gKCl/L

$\begin{array}{llll}0.3 & 0.5 & 0.8 \\ 0 & \end{array}$

(a)

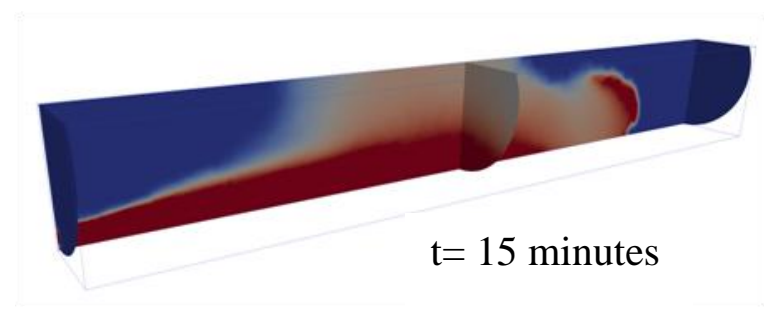

(c)

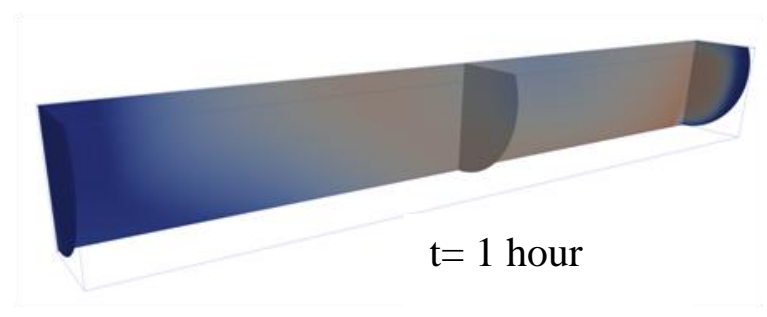

(e)

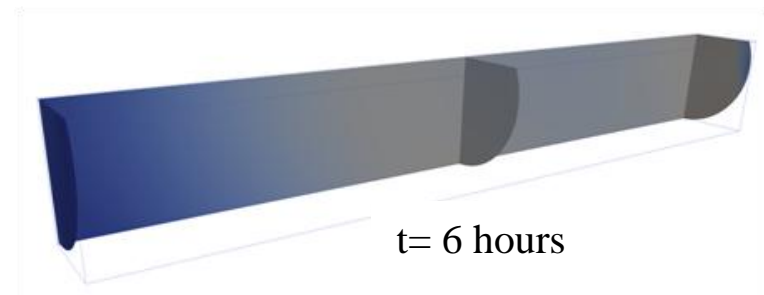

(b)

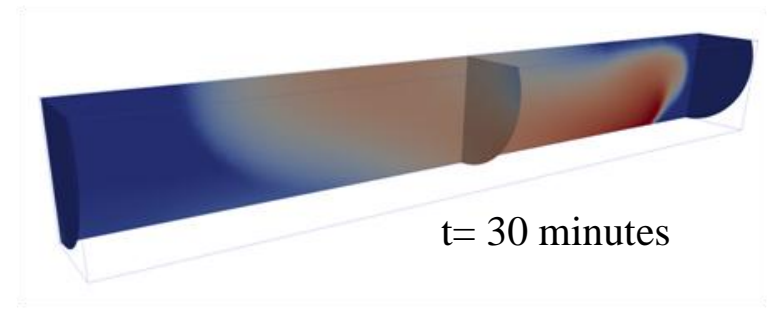

(d)

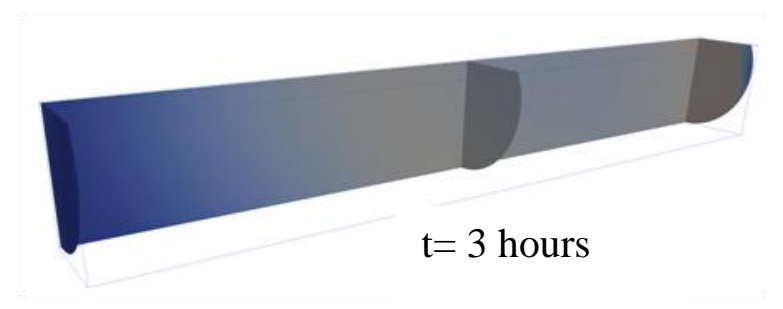

(f)

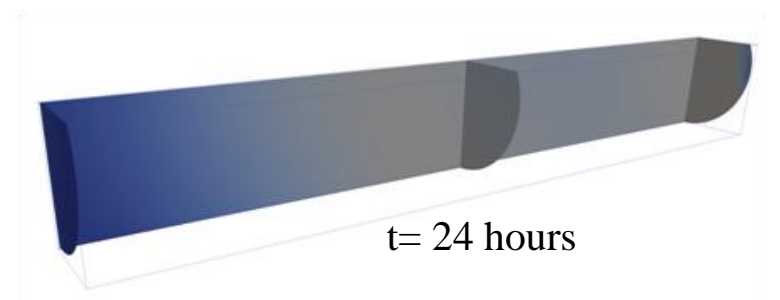

Figure 4: Contour of tracer concentration (tracer distribution) for the batch-reactor periodon middle $\mathrm{x}-\mathrm{z}$ plane and three $\mathrm{y}-\mathrm{z}$ planes $(\mathrm{x}=0,4$, and $8 \mathrm{~m})$ 

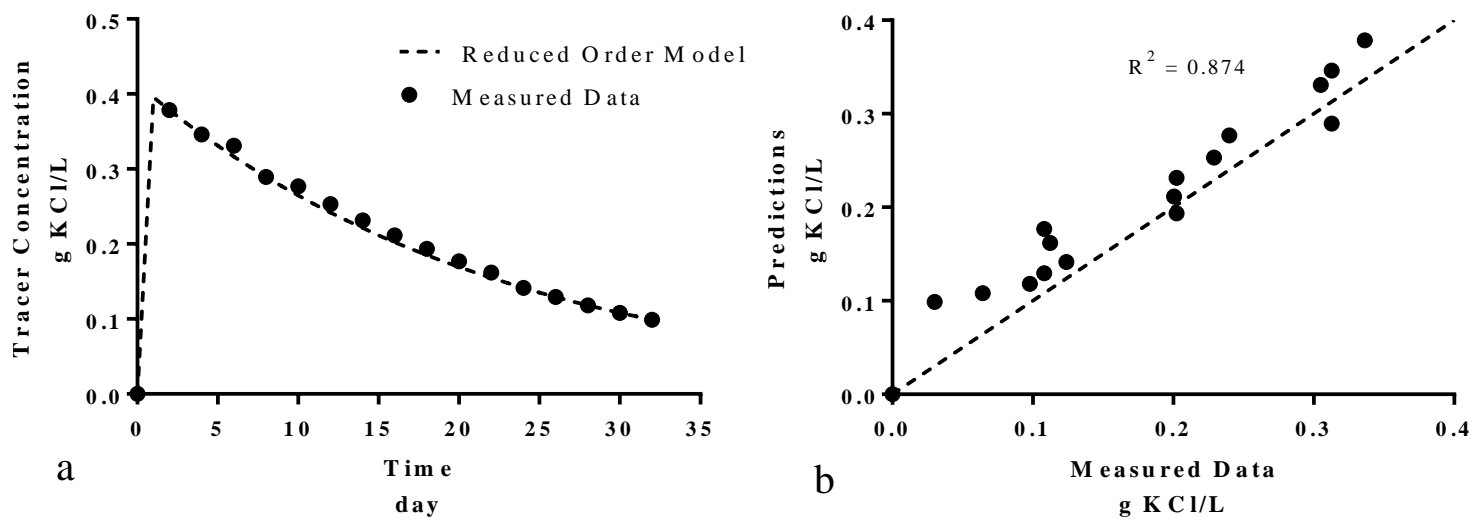

Figure 5: Comparison of predicted RTD from measured data (a) concentration versus time; (b) predictions versus measured data. 
A

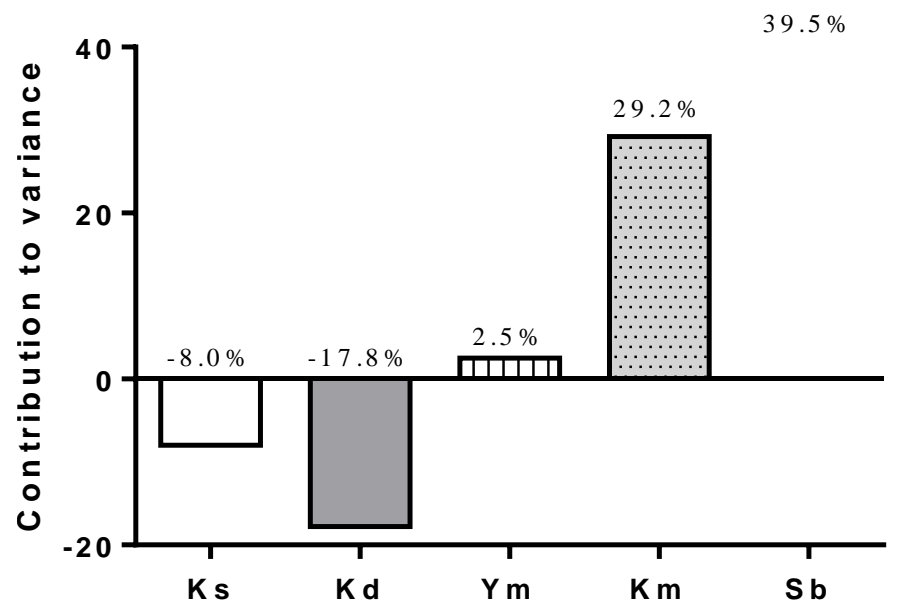

$\mathrm{B}$

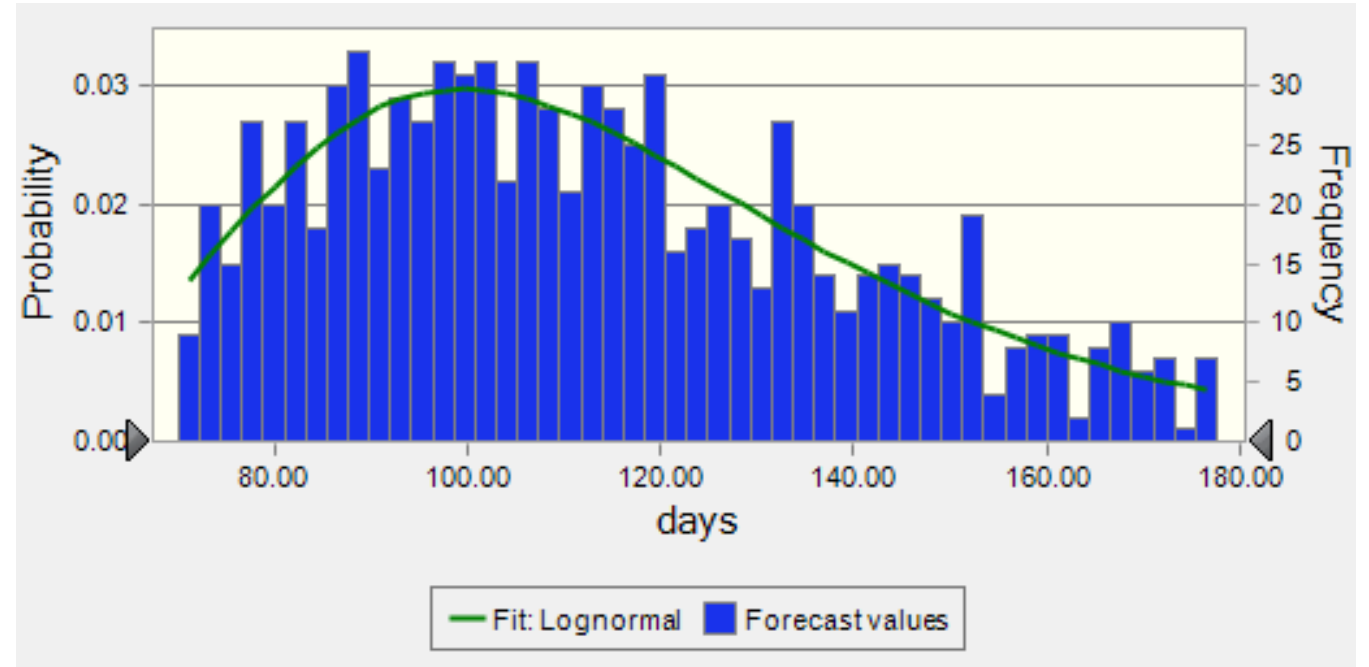

Figure 6: (A) MCRT variables sensitivity analysis and (B) MCRT frequency distribution from the Monte Carlo simulation. 